\title{
Securities Issuance Considerations As an External Funding Source for Sharia Commercial Banks
}

\author{
Ida Syafrida \\ Politeknik Negeri Jakarta, Indonesia \\ email: ida.syafrida@akuntansi.pnj.ac.id \\ Indianik Aminah \\ Politeknik Negeri Jakarta, Indonesia \\ email: indianik.aminah@akuntansi.pnj.ac.id

\section{Taufik Awaludin} \\ Universitas Pamulang, Indonesia \\ email: dosen01844@unpam.ac.id
}

\begin{abstract}
This research is to formulate dominant aspects and sub-aspects of benefits, opportunities, costs, risks for the Issuance of Sukuk and shares as an external funding source for Sharia Banks (IBs). The fundamental problem is related to the less optimal role of Islamic banking in the national economy because the market share is $5.94 \%$ (early 2019). It is necessary to increase external funding sources through the Issuance of Sukuk and shares. There were 3 IBs share issuers: BPDS, BRIS, BTPNS, and 4 IBs Sukuk issuers: BMI, BSM, BNIS, BRIS. The method uses Analytic Network Process to identify dominant aspects and sub-aspects that IBs consider to issue Sukuk and shares. The primary data from in-depth interviews with each 5 Sukuk and share issuer expert practitioners of IBs Treasury and Corporate Planning. The consideration of IBs is much influenced by the benefit and opportunity aspects. Dominant subaspects of IBs considerations in Sukuk issuance: sources of funds for capital and business expansion (benefit aspects), oversubscribed investor demand (opportunity aspects), cost of capital (cost aspects), sharia compliance risks (risk aspects). Dominant sub-aspects of public share issuance: increasing capital (benefit aspect), broad investor base (opportunity aspect), underwriter costs (cost aspect), information disclosure demands (risk aspect).
\end{abstract}

Keywords: Islamic Bank; BOCR; Shares; Sukuk

Abstrak: Penelitian ini untuk merumuskan aspek dan sub-aspek dominan dari
manfaat, peluang, biaya, dan risiko (BOCR) atas penerbitan sukuk dan saham
publik sebagai sumber pendanaan eksternal Bank Umum Syariah (BUS). Dasar
masalah terkait belum optimalnya peran perbankan syariah dalam
perekonomian nasional karena pangsa pasar yang baru mencapai 5,94\% dari
total perbankan nasional (awal tahun 2019). Ini disebabkan minimnya
permodalan dan skala industri serta individual BUS, sehingga perlu

Economica: Jurnal Ekonomi Islam - Volume 11, Nomor 2 (2020) 
Ida Syafrida, Indianik Aminah, and Taufik Awaludin

peningkatan sumber pendanaan eksternal melalui penerbitan sukuk dan saham publik. Di awal 2019 terdapat 3 BUS emiten saham: BPDS, BRIS, BTPNS dan 4 BUS emiten sukuk: BMI, BSM, BNIS, BRIS. Metode analisis data menggunakan Analytic Network Process untuk mengidentifikasi aspek dan sub-aspek dominan yang menjadi pertimbangan BUS menerbitkan sukuk dan saham publik. Data utama hasil wawancara terhadap masing-masing 5 praktisi ahli Treassury dan Corporate Planning BUS emiten saham dan emiten sukuk. Pertimbangan BUS dominan dipengaruhi aspek manfaat kemudian aspek peluang. Sub-aspek dominan pertimbangan BUS dalam penerbitan sukuk yaitu: sumber dana ekspansi usaha dan permodalan (aspek manfaat), permintaan investor berlebih (aspek peluang), biaya modal (aspek biaya), risiko kepatuhan syariah (aspek risiko). Sub-aspek dominan penerbitan saham publik yaitu: meningkatkan permodalan (aspek manfaat), luasnya basis investor (aspek peluang), biaya penjamin emisi (aspek biaya), tuntutan keterbukaan informasi (aspek risiko).

Kata Kunci: Bank Syariah; BOCR; Saham publik; Sukuk 


\section{Introduction}

The sharia financial services industry in Indonesia has experienced significant growth so that Indonesia is predicted to become one of the countries that becomes a global player in the sharia financial industry in the world. DinarStandard (2020) issued a report from the State of the Global Islamic Economic Report 2020-2021. Indonesia ranks 4th after Malaysia, Saudi Arabia, and The United Arab Emirates in developing the global halal industry, including Islamic Finance. In terms of investment, United Nation Conference on Trade and Development (2020) published the 2020 Markets Investment Report, which placed Indonesia in the top three positions after Malaysia and the United Arab Emirates, but Indonesia has better growth potential with population growth and higher gross domestic product two countries. World Bank Group (2020) published the 2020 Global Islamic Financial Report, which placed Indonesia 1st rank in the world Islamic finance industry.

The OJK (Financial Services Authority) grouped the Indonesian Sharia finance industry into sharia banking, sharia capital market, and Sharia nonbank financial industry (Otoritas Jasa Keuangan 2020b). Sharia banking consists of Sharia Commercial Banks (SCB), Sharia Business Units (SBU), and Sharia Rural Banks (SRB). Of the three groups of the Sharia finance industry, sharia banking is an industry that has existed since 1992 and is the most developed to date. Until December 2020, there were 14 SCB entities and 20 SBU entities. During the 2016-2020 period, the total assets of SCB and SBU increased by an average of $14.99 \%$ per year, financing disbursed per year increased by an average of $12.55 \%$, and third party funds increased by an average of $15.13 \%$ per year. However, when viewed from the intermediation perspective, the Financing Deposit Ratio (FDR) of sharia banking is on average 85.59\% lower than the Loan Deposit Ratio (LDR) of conventional banking, which reaches $90.96 \%$. This is considered necessary because sharia banking 
Ida Syafrida, Indianik Aminah, and Taufik Awaludin

acts as a commercial bank and investment bank to improve the real economy and encourage people's economic productivity.

Subsequently, the OJK Sharia Banking Road Map 2020-2025 explains that there are 3 (three) pillars of sharia banking development: strengthening identity, synergies, and ecosystems, licensing, regulation, and supervision (Otoritas Jasa Keuangan 2020a). This is in line with research that examined the impact of the slowdown in the growth of sharia banks in 2013-2014 and efforts to overcome it (Syafrida and Aminah 2015). For this reason, policies need to be directed at strengthening capital and business scale, because seen from the market share of sharia banks in national banking at the end of 2020, it only reached $11.28 \%$, so that the contribution of sharia banks to the national economy is still not optimal. Until the end of 2020, of the 13 Sharia Commercial Banks (SCB), only 1 SCB has entered the BUKU 3 category (core capital between IDR 5 to IDR 30 trillion), namely Bank Syariah Mandiri. 9 SCB are categorized as BUKU 2 (core capital of IDR 1 to IDR 5 trillion). The other 4 SCB are categorized as BUKU 1 (core capital of IDR 100 billion to IDR 1 trillion). Based on a study by Bank Indonesia, to achieve optimal economies of scale, banking corporations must increase their core capital to more than IDR 5 trillion or fall into the BUKU 3 category. Therefore, additional sources of funding are needed to develop sharia banks.

The limitation of internal funding sources for sharia banks can be overcome by using external funding sources, namely by issuing securities, debt (bonds/Sukuk), and investments (shares). The source of investment funds is more flexible to use than debt because it has no maturity and no routine financial obligations to investors. As of early 2019, the number of sukuk issuers was recorded at 4 SCB, namely Bank Syariah Mandiri, Bank Muamalat, BRI Syariah, and BNI Syariah. Meanwhile, the number of banks issuing public shares on the Indonesia Stock Exchange (IDX) was 43 conventional banks and three sharia commercial banks, namely Bank Panin Dubai Syariah, Bank Tabungan Pensiun Nasional Syariah, and BRI Syariah. 
Therefore, it is expected that other IBs can follow those IBs' steps in issuing Sukuk and or public shares.

The Issuance of bonds or Sukuk will have a positive impact and benefit for banks. Septiana (2010) concluded that the impact of the Issuance of subordinated bonds could increase capital, interest income, and LDR. Meanwhile, Fatwandari (2010) concluded that bond issuance helps increase the CAMELS factor for banks. Sapulete and Manurung (2012) revealed that the Issuance of subordinated bonds at commercial banks could significantly increase ROA and ROE. Alsaeed (2012) revealed that the company issued Sukuk as a diversified funding source from issuers' perspective.

According to the IDX, corporations that issue public shares will benefit from new funding sources, provide a competitive advantage for business development, merge or acquire other companies with financing through the Issuing of shares, and enhance business continuity, image, and value. Sources of funding through the Issuance of securities in the form of shares, both conventional and Sharia shares, are supported by several studies. Poulsen and Stegemoller (2008) showed that companies would move to public ownership through Initial Public Offering (IPO) when they have more significant growth opportunities. Sell-out appears to be preferable when managers are liquidating more of the firm and facing financial constraints. According to Kim and Weisbach (2008), one of the motives for offering equity is to increase capital for investment. Market timing and investment financing are the motivations for offering equity. Sulong et al. (2017) finding is consistent with previous research, which showed no significant difference between the initial performance of Sharia and non-sharia IPO.

Based on that description, Sharia banks need external funding sources in investments and long-term debt. With this additional capital or funds, sharia banks can fulfill their intermediation role more optimally and make a more outstanding contribution to the national economy. To increase funding sources, it is necessary to study the benefits, opportunities, costs and risks 
Ida Syafrida, Indianik Aminah, and Taufik Awaludin

Sharia Commercial Banks considers in issuing Sukuk and public shares based on the knowledge or experience of experts related to the matter. Thus, the results of this study can be used as material for consideration for IBs who will take alternative Issuance of securities to increase their funding sources.

\section{Literature review}

In Shari'a Standard No.17 concerning Sukuk Investment issued by the Accounting and Auditing Organization for Islamic Financial Institutions (AAOIFI 2015), Sukuk is certificates of equal value representing an integral part in the ownership of tangible benefits or services or ownership of assets. A particular project asset or investment activity, which occurs after receipt of Sukuk funds, closing of orders, and the funds received, is used according to the Sukuk issuance purpose. The advantage of Sukuk lies in its structure which is based on tangible assets, which means that the value of the Sukuk will always be related to the value of the underlying assets. With this concept, it is expected that funding through Sukuk is based on the issuance value of the underlying asset, thereby minimizing the possibility of funding facilities exceeding the asset value. Another characteristic of Sukuk is that the Sukuk holder is entitled to a portion of the income generated from the Sukuk assets and the rights from the sale of the Sukuk assets. Suppose the certificate reflects an obligation to the holder. In that case, the sukuk cannot be traded in the secondary market to become a long-term instrument held to maturity or sold at nominal value.

According to the fatwa of the National Sharia Council of the Indonesian Ulema Council No. 40/DSN-MUI/X/2003 concerning the Capital Market and General Guidelines for the Implementation of Sharia Principles in the Capital Market Sector, sharia shares are proof of ownership of a company that meets the criteria that it does not conflict with sharia principles (Dewan Syariah Nasional Majelis Ulama Indonesia 2003). Sharia shares are securities that are equity participation in a company that does not violate sharia principles. Contracts that occur in sharia shares can be implemented with mudharabah 
and musyarakah contracts. Public offering (go public) according to Capital Market Law no. 8 of 1995 is securities offering activity executed out by issuers to sell securities to the public based on the procedures regulated in the Capital Market Law and its Implementing Regulations (Republik Indonesia 1995).

In terms of capital structure, a public offering is a company's effort to obtain fresh funds from the general public or investors by issuing new shares or, in other words issuing shares in the portfolio. According to Syafrida and Aminah (2015), there are three terms of public offerings or Initial Public Offering (IPO): issuers, public companies, and listed companies. Issuers are companies that offer their securities to the investor community through a public offering. This definition emphasizes more on the form of activity. A public company is a limited liability company whose shares are owned by at least 300 shareholders and have a minimum paid-up capital of IDR 3 billion. This definition emphasizes the quantity aspect of the distribution of securities and the company's capital aspect. A Listed Company is a public company that shares its shares on a stock exchange. Public companies are generally public, but several public companies do not list their shares on the stock exchange. A limited offer (tender offer) is an offer through the mass media to obtain equity securities through purchase or exchange with other securities. Transactions in the context of tender offers can be arranged both inside and outside the stock exchange. Over-the-counter transactions are transactions carried out directly between buyers and sellers.

The bank's capital structure can be sourced from long-term debt (bonds/Sukuk) and equity participation. External sources of funds originating from bond/Sukuk and stock investors can increase the capital of sharia banks, which will impact increased financing and assets. However, banks need to consider the factors that affect their capital structure. Several studies related to bank capital structure: According to Manopo (2013), who examined banks that went public on the Indonesia Stock Exchange (IDX) for the 2008-2010 period, sales growth, sales stability, and company size affected the capital 
structure. Therefore, decision-making related to financial decisions will affect the progress and viability of banking in the future. Puspita and Kusumaningtias (2010) concluded that the capital structure of banks listed on the IDX is essential in performing their operational activities. Asset structure, profitability, and dividend policy affect the bank's capital structure. In Susyanti (2008), bank profitability has a significant negative effect, while the growth of bank assets and liquidity has a significant positive effect on the financial capital structure of the "X" Bank. Banks need to consider these factors in determining their capital structure.

\section{Methods}

The previous researcher used more quantitative methods with an econometric approach, while the rest used qualitative methods with a literature study approach and expert interviews. The research method we use is different from them. We employed a mixed-method, namely qualitative and quantitative, using library research methods and interviews. To combine the two methods, the researchers used the ANP method.

This research was conducted around the Jakarta area. The location was chosen based on purposive sampling and convenience sampling, where respondents can be found because the respondents of this study are experts. All of them work at the head office in Jakarta. The selected respondents have knowledge and experience and can answer research questions to gain theoretical insight (Saunders, Lewis, and Thornhill 2009). For this reason, the researcher uses expert respondents who are company leaders in the corporate planning division and the treasury division who directly handle the company's process in deciding the Issuance of shares or Sukuk. The data used are primary data and secondary data. Primary data were taken from the interviews (in-depth interviews) with each of 5 IBs expert practitioners, issuers of Sukuk, and issuers of public shares. Secondary data were obtained from the prospectus of stock issuance, book literature, journals, theses, 
dissertations, working papers, and other published reports closely related to the problem of sharia bank funding sources.

Data were collected by conducting in-depth interviews with structured questions (see Appendix 1) to respondents and supported by literature studies that researchers had obtained previously. The interview was recorded for decomposition. Subsequently, the researcher made a pairwise comparison questionnaire where respondents were asked to determine which aspect or sub-aspect was more influential in producing a ratio-scaled data output. The researchers used the Analytic Network Process method to determine the dominant factors chosen by respondents regarding aspects and sub-aspects of BOCR in deciding the Issuance of shares and Sukuk. This method is used in the form of a solution considering adjusting the complexity of the problem by parsing the synthesis with a priority scale that produces the most significant priority effect. ANP is also able to explain the dependency model and feedback factors systematically. Decision-making in the application of ANP is to consider and validate practical experience (Saaty and Vargas 2013).

There are several phases in this research. Phase 1 is constructing the ANP model based on the literature review of theoretical and empirical data. Phase 2 is the quantification model. Using the questions in the ANP questionnaire in the form of pairwise comparison (benchmarking partner) between elements in the cluster to determine which of the two more significant influences (more dominant) and how big the difference is through a numerical scale of 1-9. Phase 3 is the Synthesis and Analysis. Synthesis and analysis of the results are based on the geometric mean (GM) and rater agreement. Geometric Mean is the result of an opinion on the group to form a consensus. At the same time, rater agreement is a measure that indicates the level of conformity (approval) of the respondents to a problem in one cluster. The instrument used to measure rater agreement was Kendall's Coefficient of Concordance $(W ; 0<W \leq$ 1). $W=1$ indicates a perfect match. 
Ida Syafrida, Indianik Aminah, and Taufik Awaludin

\section{Result and discussion}

Based on the results of interviews with IBs Sukuk practitioners and literature studies, information is obtained regarding the factors of issuing Sukuk based on the benefits, opportunities, costs, and risks as follows:

\section{Benefit aspect}

In benefits, four sub-aspects are considered or influenced: i) sources of funds for capital and business expansion, ii) Sharia market profiling and benchmarking, iii) multi-contracts, coupons, and terms, iv) increasing liquidity, efficiency, and profitability.

Companies issue Sukuk as a diversified source of funding (Alsaeed 2012) and can change and improve the bank's capital structure (Awaludin et al. 2016). Several issues related to the Issuance of Sukuk are the need for the secondary market needs, yields that look at the benchmarks, standardization of Sukuk scheme agreements (Abdo 2014). Zin et al. (2011), Sukuk can be structured together with different techniques. While conventional bonds are promised to repay the loan, Sukuk represents partial ownership in debt (al Murabaha Sukuk), assets (al Ijara Sukuk), projects (al Istishna Sukuk), business (al Musharaka Sukuk), or investments (al Istithmar Sukuk). Various structures of Sukuk are not found in the Qur'an and Sunnah but are the result of context-based ijtihad developed by Islamic scholars and thinkers (Saeed and Salah 2014). Akbarullah (2011) found that the Sukuk issued impacted increasing the amount of financing disbursed, increasing financial ratios in ROE, FDR, and NIM while decreasing CAR.

\section{Opportunity aspect}

In the opportunity, four sub-aspects are considered or influenced: i) a small number of issuers, ii) oversubscribed investor demand, iii) broad investor base, iv) solid regulatory support. 
Wicaksana (2014) opportunities in issuing Sukuk are a very responsive market, the great demand for Islamic bonds from Middle Eastern investors, and funding for mining projects that require many funds very much. Armadiyanti (2013), Sukuk issuance opportunities are Sukuk as a potential for safe liquidity distribution, a prominent Indonesian Muslim population, promising Indonesian economic growth, and an alternative to the state budget deficit reserve and monetary policy.

\section{Cost aspect}

In the cost, four sub-aspects are considered or influenced: i) cost of capital, ii) cost of debt, iii) cost of underwriting, iv) cost of Issuance.

Jiwandaru and Taufiqurrahman (2014) stated that in general, some costs arise from the Issuance of Sukuk, including: First, Cost of capital: Cost of capital is a critical factor in decisions related to the use of debt capital or equity capital. The cost of capital is the cost that must be incurred. For example, to obtain capital from debt, preferred stock, common stock, and retained earnings to finance the company's investment. The concept of the cost of capital is only relevant for long-term decisions.

Second, Cost of debt; In calculating the cost of capital for Sukuk, no interest is known. The calculation of the rate of return demanded by Sukuk investors varies by contract. In an al Ijara Sukuk, the issuer pays a fixed rental fee to the investor. While in an al Mudharaba Sukuk, the issuer pays the investor's profit according to the profit generated.

Third, Floating Costs, Companies seeking long-term capital have two types of floating costs-first, the distribution of underwriters (spreads). Second, publishing costs include printing and engraving, legal, accounting, trust, and several other components.

Diaw et al. (2012) revealed that partnership-based Sukuk also has advantages in capital cost efficiency and structural simplicity and is the correct 
Ida Syafrida, Indianik Aminah, and Taufik Awaludin

Sukuk type for productive business activities. On the other hand, Pribadi and Wibowo (2019) concluded that leverage has a negative and significant influence on the company's decision to issue Sukuk.

\section{Risk aspect}

In risk, four sub-aspects are considered or influenced: i) default risk, ii) sharia compliance risk, iii) interest rate risk, iv) risk of loss of underlying assets.

According to Nanaeva and Mammadov (2010), the risks of conventional bonds are as follows: First, Interest rate risk: bond yields have an inverse relationship with interest rate movements as an income instrument. When interest rates start to grow, bond prices will fall. Conversely, the longer the bond's maturity, the higher the potential for interest rate increases. So this will increase the level of interest rate risk. Second, Default risk: there is a risk that the bond issuer can not make regular payments (coupons) or the principal amount of the bonds.

Wahid (2010) stated that the forms of risk of loss for the originator/issuer which are generally related to assets are as follows: 1) Assets risk loss, Loss of assets due to natural disasters or fire and asset impairment. 2) Failure to buy back, If the originator of bankruptcy is in a state of not repurchase the assets within the period specified in the contract.

One of the requirements for issuing the Sukuk is a halal core business that does not conflict with the substance of Fatwa No: 20/DSN-MUI/IV/2001. The fatwa explains various types of business activities that are prohibited because they are contrary to Islamic principles. In addition, issuers in issuing Sukuk must comply with sharia compliance related to the Sukuk structure by obtaining endorsement from the Sharia Supervisory Board. El Shazly and Tripathy (2013) revealed that the Sukuk market faces a significant challenge: the underlying asset that generates revenue streams must comply with sharia law. 
Figure 1. BOCR priority in issuing sukuk

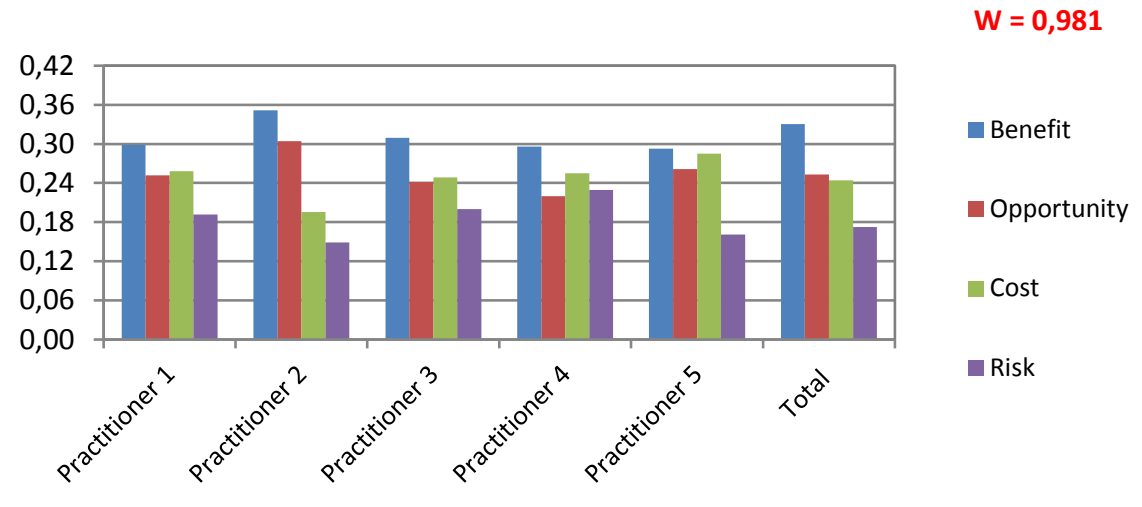

Figure 1 is the results of processing the BOCR aspect in the ANP for the Issuance of Sukuk. In Figure 1, all respondents think that the dominant aspect for IBs in deciding to issue Sukuk is the benefit aspect, followed by the opportunity aspect with a high conformity value ( $\mathrm{W}=0.981)$. Then only consider the cost aspect and lastly, the risk aspect. Thus, it can be concluded that benefits and opportunities are dominant aspects for IBs in deciding to issue Sukuk as a source of funding. Therefore, if the IBs decide to issue Sukuk, the IBs will first consider the benefits and opportunities that the IBs will get from these activities.

If seen in more detail, the ANP results regarding the dominant subaspects that IBs consider in issuing Sukuk are as figure 2. In Figure 2, it can be concluded that overall, respondents think that the dominant sub-aspect of the benefits aspect is the source of funds for capital and business expansion. Thus, the main benefit of issuing Sukuk for IBs is to increase funds for business, in this case, capital and financing. From the opportunity aspect, the most critical sub-aspect is the oversubscribed investor demand. Sukuk offered by IBs are

Economica: Jurnal Ekonomi Islam - Volume 11, Nomor 2 (2020) 
Ida Syafrida, Indianik Aminah, and Taufik Awaludin

always oversubscribed, so it becomes a consideration for IBs to participate in issuing Sukuk. The cost of capital is the most dominant sub-aspect of the cost aspect. Sukuk provides coupon income regularly so that the cost of capital becomes the most critical consideration in terms of costs. Finally, in the risk aspect, the dominant sub-aspect considered is Sharia compliance risk. Issuers in issuing Sukuk must meet the requirements of sharia compliance, so this is a consideration in issuing Sukuk.

Figure 2. Priority description on the BOCR of sukuk issuance

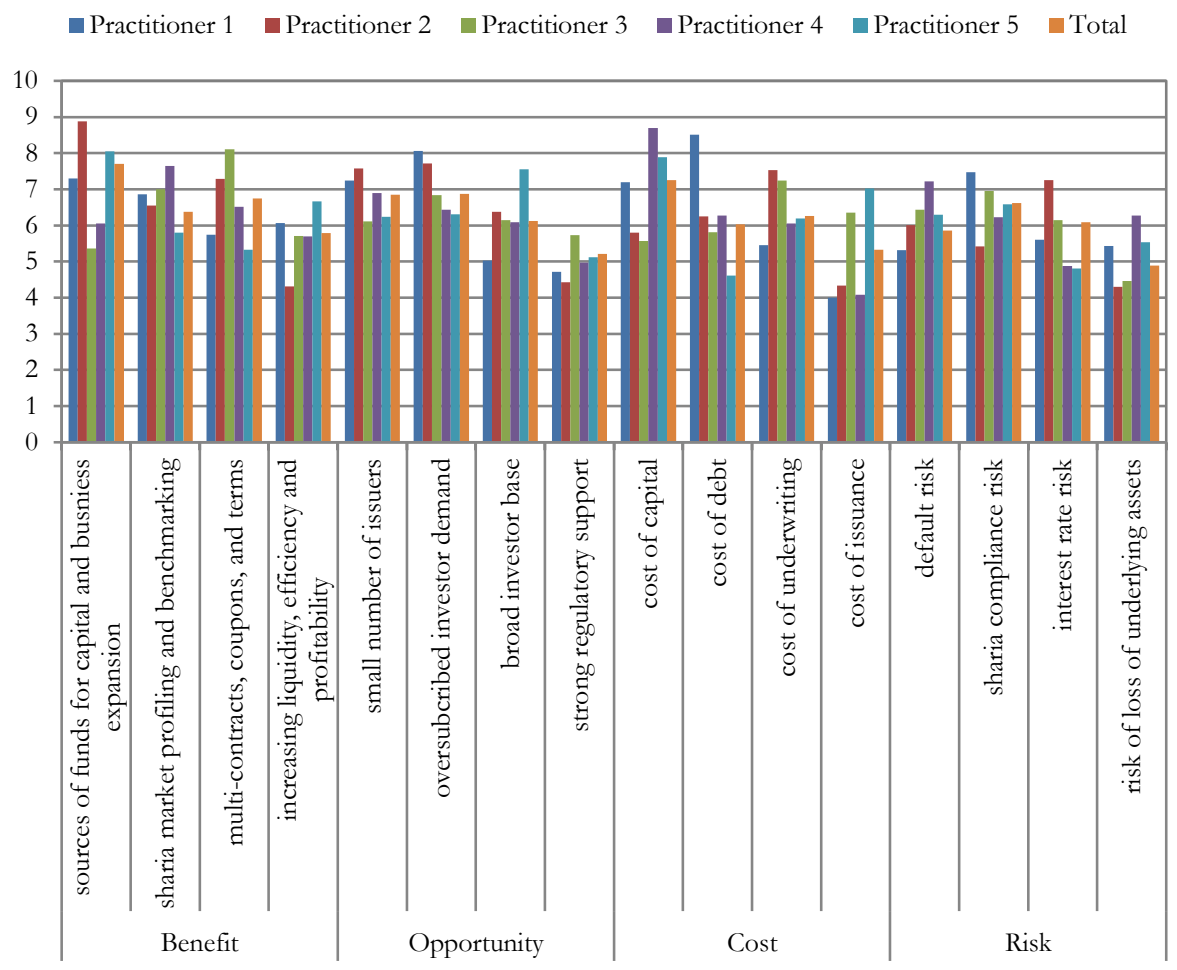


Based on the results of interviews with IBs share practitioners and literature studies, information is obtained regarding the factors of issuing share based on the benefits, opportunities, costs, and risks as follows:

In benefits, four sub-aspects are considered or influenced: i) increase capital, ii) source of funding, iii) business expansion, iv) improve the company's reputation. This is in line with the research results (Kim and Weisbach 2008); (Lee and Lee 2008); (García-Pérez-de-Lema, Duréndez, and Mariño 2011), which concluded that companies conduct stock offerings to increase investment capital, sources of financing, legitimacy, and reputation, and risk diversification.

In the opportunity, four sub-aspects are considered or influenced: i) broad investor base, ii) intelligent choice of underwriter, iii) solid regulatory support, iv) favorable investment condition. This opportunity condition is in line with the research results (Pham et al. 2003); (Bildik and Yilmaz 2006); (Poulsen and Stegemoller 2008). They show that companies move to public ownership through an IPO with more significant growth opportunities: number of potential investors, investment bank reputation, market conditions, and market timing.

In the cost, four sub-aspects are considered or influenced: i) underwriter cost, ii) service fees for supporting institutions and professions, iii) emission registration fees, iv) other costs, such as printing, advertising, listing on the stock exchange. The costs generally borne by companies related to sharing Issuance are discussed in the study (Benninga et al. 2005); (Asker, FarreMensa, and Ljungqvist 2015).

In risk, four sub-aspects are considered or influenced: i) reduced ownership requirements, ii) resistance to changes in ownership, iii) stricter reporting requirements, iv) information disclosure demands. Several studies discuss the risks of issuing shares for companies. There are risks associated with going public, such as loss of shareholder control, high reporting 
Ida Syafrida, Indianik Aminah, and Taufik Awaludin

requirements, lack of resources, and resistance to change (Becchetti and Trovato 2002); (Berggren et al. 2000). In addition, the openness of requirements can limit innovation (Wies and Moorman 2015).

Figure 3 is the results of processing the BOCR aspect in the ANP for the Issuance of public shares:

In Figure 3, all respondents think that the dominant aspect for IBs in deciding to issue public shares is the benefit aspect, followed by the opportunity aspect with a reasonably high conformity value $(\mathrm{W}=0.779)$. Then only consider the cost aspect and lastly, the risk aspect. Thus, it can be concluded that the benefits and opportunities are the dominant aspects for IBs in deciding to issue public shares as a source of funding. Therefore, if the IBs decide to issue public shares, the IBs will first consider the benefits and opportunities that the IBs will receive from these activities.

Figure 3. BOCR priority in issuing public shares

$\mathrm{W}=0.779$

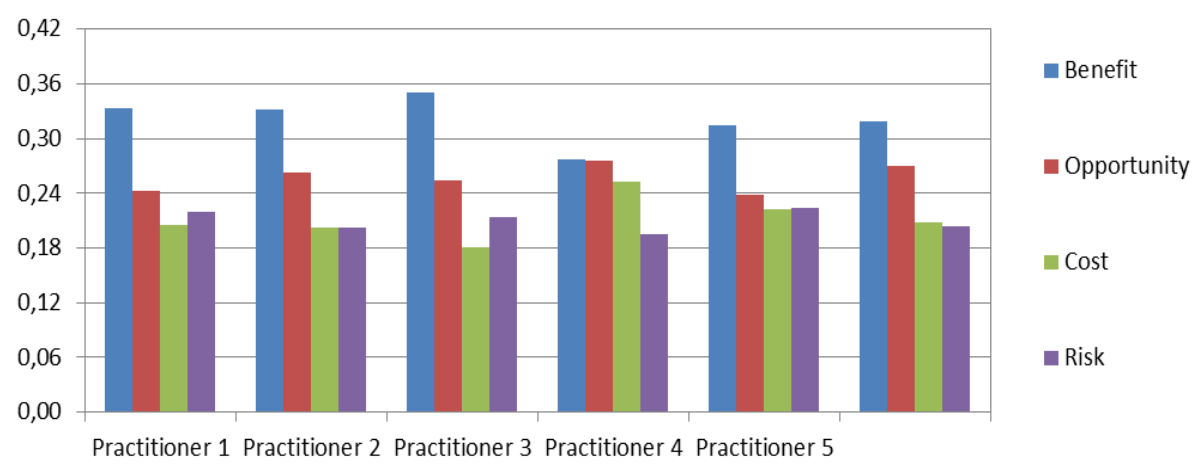


Figure 4. Priority description on the BOCR of public share issuance

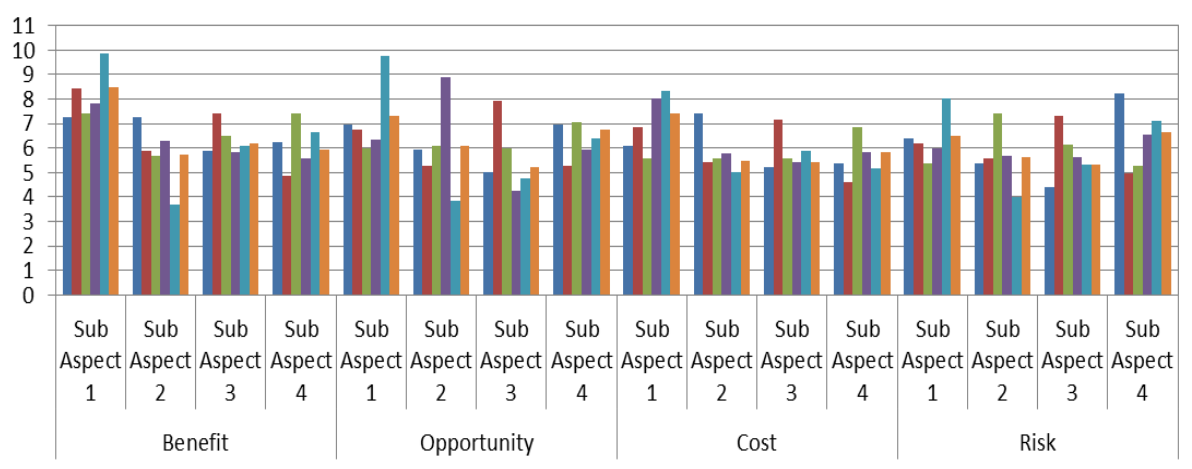

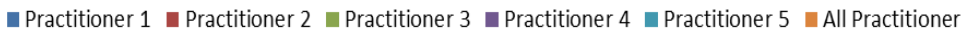

If seen in more detail, the ANP results regarding the dominant subaspects that IBs consider in issuing share public are as figure 4. In Figure 4, it can be seen that overall, respondents think that the dominant sub-aspect of the benefit aspect is to increase capital. Thus, the main benefit of issuing public shares for IBs is to increase capital. The most crucial sub-aspect in the opportunity aspect is the broad investor base. Investors who can buy IBs public shares can come from investors who consider sharia factors in investing and general investors so that the sharia IBs stock market is quite broad. The underwriting fee is the most dominant sub-aspect of the underwriter fee. The existence of an underwriter as an underwriter is to assist issuers in going public from beginning to end. The underwriter also guarantees the sale of shares offered by the issuer, so th.e costs for the underwriter are also a major issue. In the risk aspect, the dominant sub-aspect considered is the demand for information disclosure. Information disclosure regulations make IBs have to be ready with all reporting following standards to the Financial Services Authority and the public and have publication facilities for the general public. 
Ida Syafrida, Indianik Aminah, and Taufik Awaludin

\section{Conclusion}

Based on ANP's analysis of the BOCR aspect, the dominant aspect that the IBs consider in issuing Sukuk and public shares is the benefit aspect, then the opportunity aspect. Subsequently, the dominant sub-aspects of IBs considerations in issuing Sukuk are sources of funds for capital and business expansion (benefit aspect), oversubscribed investor demand (opportunity aspect), cost of capital (cost aspects), sharia compliance risks (risk aspects). Hereafter the dominant sub-aspects of IBs considerations in issuing public shares are to increase capital (benefit aspect), broad investor base (opportunity aspect), underwriter cost (cost aspect), information disclosure demands (risk aspect).

Suggestions for Sharia Commercial Banks that have never issued shares or Sukuk to increase capital: Issuance of shares and Sukuk can be a positive alternative to increase the source of funds for IBs because profits and opportunities are more dominant than the costs and risks. In addition, IBs issuers that have conducted IPOs have proven successful with demand exceeding supply (oversubscribe) and improving the bank's reputation (profile image). Suggestions for further researchers to explore sources of external bank funding from other alternatives.

\section{Acknowledgment}

The authors would like to thank the Directorate of Research and Community Service of the Ministry of Research Technology/National Research and Innovation Agency and Ministry of Education and Culture of Indonesia for providing financial assistance and supporting the completion of this research. 


\section{References}

AAOIFI. 2015. Accounting, Auditing and Governance Standards. Edited by AAOIFI. December 2. Manama, Bahrain: Accounting and Auditing Organization for Islamic Financial Institutions.

Abdo, Alaa. 2014. "A Critical Review of the Sukuk Market A Qualitative Study to Identify Current Risks and Opportunities." Dissertaion Submitted in Part Fulfilment of the Degree of Master in Business Administration,Dublin Business School, 1-145. https://esource.dbs.ie/handle/10788/1792.

Akbarullah, Muhammad Handriyo. 2011. "Dampak Penerbitan Sukuk Terhadap Kinerja Bank Syariah (Studi Kasus PT Bank Syariah Mandiri).” Depok: Program Pascasarjana Universitas Indonesia. http://lib.ui.ac.id.

Alsaeed, Khalid, Sulaiman. 2012. "Sukuk Issuance in Saudi Arabia: Recent Trends and Positive Expectations."

Armadiyanti, Putri. 2013. "Peluang Dan Tantangan Perkembangan Obligasi Syariah (Sukuk) Di Indonesia." Jurnal Akuntansi AKUNESA 2 (1).

Asker, John, Joan Farre-Mensa, and Alexander Ljungqvist. 2015. "Corporate Investment and Stock Market Listing: A Puzzle?" Review of Financial Studies 28 (2): 342-90. https://doi.org/10.1093/rfs/hhu077.

Awaludin, Taufik, Irfan Syauqi Beik, and Rifki Ismal. 2016. "The LessInterrested of Islamic Bank for Issuing Sukuk." Walisongo: Jurnal Penelitian Sosial Keagamaan 24 (1): 37. https://doi.org/10.21580/ws.24.1.693.

Becchetti, Leonardo, and Giovanni Trovato. 2002. "The Determinants of Growth for Small and Medium Sized Firms. The Role of the Availability of External Finance." Small Business Economics 19 (4): 291-306. http://www.jstor.org/stable/40229240.

Benninga, Simon, Mark Helmantel, and Oded Sarig. 2005. "The Timing of Initial Public Offerings." Journal of Financial Economics 75 (1): 115-32. https://doi.org/10.1016/j.jfineco.2003.04.002.

Berggren, Björn, Christer Olofsson, and Lars Silver. 2000. "Control Aversion and the Search for External Financing in Swedish SMEs." Small Business Economics 15 (3): 233-42. https://doi.org/10.1023/A:1008153428618. 
Ida Syafrida, Indianik Aminah, and Taufik Awaludin

Bildik, Recep, and Mustafa Kemal Yilmaz. 2006. "The Market Performance of Initial Public Offerings in the Istanbul Stock Exchange." SSRN Electronic Journal, 49-76. https://doi.org/10.2139/ssrn.952526.

Dewan Syariah Nasional Majelis Ulama Indonesia. 2003. Fatwa Nomor: 40/DSN-MUI/X/2003. Pasar Modal Dan Pedoman Umum Penerapan Prinsip Syariah Di Bidang Pasar Modal. Indonesia.

Diaw, Abdou, Obiyathulla Ismath Bacha, and Ahcene Lahsasna. 2012. "Incentive-Compatible Șukūk Mushārakah for Private Sector Funding." ISRA International Journal of Islamic Finance 4 (1): 39-80. https://doi.org/10.12816/0002736.

DinarStandard. 2020. "State of the Global Islamic Economy Report 2020/21," 2020.

Fatwandari, Reny Julianie. 2010. “Analisis Pengaruh Penerbitan Obligasi Dan Penawaran Umum Terbatas Terhadap Penilaian Camels PT Bank XYZ, Tbk." Depok: Universitas Indonesia. http://lib.ui.ac.id/detail.jsp?id=136249.

García-Pérez-de-Lema, D, A Duréndez, and T Mariño. 2011. "A Strategic Decision for Growth, Financing and Survival of Small and Medium Family Businesses: Going Public in an Alternative Stock Market (MAB)." Economics and Finance Review 1 (8): 31-42.

Jiwandaru, Burhanuddin, and Muhammad Rizal Taufiqurrahman. 2014. "Analisis Komparatif Biaya Hutang Sukuk Dan Obligasi Perusahaan." Tazkia Islamic Finance and Business Review 5 (2). https://doi.org/10.30993/tifbr.v5i2.43.

Kim, Woojin, and Michael S. Weisbach. 2008. "Motivations for Public Equity Offers: An International Perspective." Journal of Financial Economics 87 (2): 281-307. https://doi.org/10.1016/j.jfineco.2006.09.010.

Lee, Yoon-Jun, and Jeong-Dong Lee. 2008. "Strategy of Start-Ups for IPO Timing across High Technology Industries." Applied Economics Letters 15 (11): 869-77. https://doi.org/10.1080/13504850600820650.

Manopo, Widy Fimber. 2013. "Faktor-Faktor Yang Mempengaruhi Struktur Modal Perbankan Yang Go Public Di Bei Tahun 2008-2010." Jurnal Riset Ekonomi, Manajemen, Bisnis Dan Akuntansi 1 (3): 653-63. https://doi.org/10.35794/emba.1.3.2013.1872. 
Nanaeva, Zhamal, and Rauf N Mammadov. 2010. "Thoughts on Sukuk and the Risk of Default." Islamic Finance News, 2010. https://www.researchgate.net/publication/329786438_Thoughts_on_S ukuk_and_the_Risk_of_Default.

Otoritas Jasa Keuangan. 2020a. "Laporan Publikasi Roadmap Perbankan Syariah 2020-2025." Jakarta.

_- - 2020b. "Laporan Publikasi Statistik Perbankan Syariah." Jakarta.

Pham, Peter K., Petko S. Kalev, and Adam B. Steen. 2003. “Underpricing, Stock Allocation, Ownership Structure and Post-Listing Liquidity of Newly Listed Firms." Journal of Banking \& Finance 27 (5): 919-47. https://doi.org/10.1016/S0378-4266(02)00241-8.

Poulsen, Annette B., and Mike Stegemoller. 2008. "Moving from Private to Public Ownership: Selling Out to Public Firms versus Initial Public Offerings." Financial Management 37 (1): 81-101. https://doi.org/10.1111/j.1755-053X.2008.00005.x.

Pribadi, Sukma Kukuh, and Buddi Wibowo. 2019. "The Analysis of Company Decisions in Choosing Sukuk and Bonds Using Logit Model." Economica: Jurnal Ekonomi Islam 10 (1): 141-64. https://doi.org/10.21580/economica.2019.10.1.3211.

Puspita, Gita Cahya, and Rohmawati Kusumaningtias. 2010. "Pengaruh Struktur Aktiva, Profitabilitas, Kebijakan Dividen Terhadap Struktur Modal Pada Perbankan Yang Terdaftar Di Bursa Efek Indonesia Pada Tahun 2005-2009." AKRUAL: Jurnal Akuntansi 2 (1): 76. https://doi.org/10.26740/jaj.v2n1.p76-91.

Republik Indonesia. 1995. Undang-Undang Republik Indonesia No 8 Tahun 1995 Tentang Pasar Modal.

Saaty, Thomas L., and Luis G. Vargas. 2013. Decision Making with the Analytic Network Process. Vol. 195. International Series in Operations Research \& Management Science. Boston, MA: Springer US. https://doi.org/10.1007/978-1-4614-7279-7.

Saeed, A., and O. Salah. 2014. "Development of Sukuk: Pragmatic and Idealist Approaches to Sukuk Structures 1."

Sapulete, Archie Marlon, and Adler Haymans Manurung. 2012. "Pengaruh Penerbitan Obligasi Subordinasi Dan Rasio Keuangan Terhadap Profitabilitas Bank," no. November: 1-24.

Economica: Jurnal Ekonomi Islam - Volume 11, Nomor 2 (2020)

https://journal.walisongo.ac.id/index.php/economica 
Ida Syafrida, Indianik Aminah, and Taufik Awaludin

https://www.researchgate.net/publication/264554124_Pengaruh_Pen erbitan_Obligasi_Subordinasi_dan_Rasio_Keuangan_terhadap_Profitabili tas_Bank.

Saunders, M, P Lewis, and A Thornhill. 2009. Research Methods for Business Students. Always Learning. Prentice Hall.

Septiana, Tian. 2010. "Dampak Penerbitan Obligasi Subordinasi Terhadap Struktur Modal PT. Bank DKI." Universitas Indonesia. https://library.ui.ac.id/detail?id=136487\&lokasi=lokal.

Shazly, Mona R. El, and Pragya Tripathy. 2013. "Sukuk Structures, Profiles and Risks." Isfin, $1-18$. https://www.isfin.net/sites/isfin.com/files/sukuk_structures_profiles_a nd_risks.pdf.

Sulong, Z, N A C Embi, and M R Ariffin. 2017. "Performance of Initial Public Offerings: Does Shariah Compliance Extensiveness Make A Difference?" International Journal of Accounting 2 (6): 190-205.

Susyanti, Jeni. 2008. "Profitabilitas, Pertumbuhan Aktiva, Ukuran Perusahaan, Struktur Aktiva, Dan Likuiditas Terhadap Struktur Modal PT Bank Syari'ah ' $\mathrm{X}$ ' Tbk." IQTISHODUNA 4 (3). https://doi.org/10.18860/iq.v0i0.268.

Syafrida, I., and I. Aminah. 2015. "Faktor Perlambatan Pertumbuhan Bank Syariah Di Indonesia Dan Upaya Penanganannya." Jurnal Ekonomi \& $\begin{array}{lllll}\text { Bisnis } & \text { PNJ } & 14 & \text { (1): } & 13473 .\end{array}$ https://doi.org/10.32722/eb.Vol14.No.1.2015.pp.

United Nation Conference on Trade and Development. 2020. "World Investment Report 2020." Jenewa (SW).

Wahid, Nazaruddin Abdul. 2010. Sukuk: Memahami \& Membedah Obligasi Pada Perbankan Syariah. Yogyakarta: Ar-Ruzz Media.

Wicaksana, Moch. Zulfiqar Agung. 2014. "Peluang Dan Tantangan Obligasi Syariah Di Indonesia: Sebuah Tinjauan Konseptual." Jurnal Akuntansi AKUNESA 2 (3). https://jurnalmahasiswa.unesa.ac.id/index.php/jurnalakuntansi/article/view/6766/3511.

Wies, Simone, and Christine Moorman. 2015. "Going Public: How Stock Market Listing Changes Firm Innovation Behavior." Journal of Marketing Research 52 (5): 694-709. https://doi.org/10.1509/jmr.13.0289. 
World Bank Group. 2020. "Overview of the Global Islamic Financial Services Industry." In Global Islamic Finance Report 2020.

Zin, Mohamad Zaid Mohd, Ahamad Asmadi Sakat, Nurfahiratul Azlina Ahmad, Mohd Roslan, Mohd Nor, Azri Bhari, Saurdi Ishak, and Mohd Sapawi Jamain. 2011. "The Effectiveness of Sukuk in Islamic Finance Market." Australian Journal of Basic and Applied Sciences 5 (12): 472-78.

Economica: Jurnal Ekonomi Islam - Volume 11, Nomor 2 (2020)

https://journal.walisongo.ac.id/index.php/economica 
Ida Syafrida, Indianik Aminah, and Taufik Awaludin 